\title{
WSTĘP DO DEBATY O PRACY REPRODUKCYJNEJ
}

\section{PRAKTYKA TEORETYCZNA}

W prezentowanym numerze „Praktyki Teoretycznej” znalazły się teksty na różne sposoby konceptualizujące pracę reprodukcyjną na gruncie teorii marksistowskiej. Być może najistotniejszym z nich jest „Kapitał” a pleć Silvii Federici, włoskiej badaczki autonomistycznej i aktywistki ruchu „Płaca za pracę domową”. Zarówno publikowany artykuł, jak i cały dorobek naukowy i polityczny autorki pokazują, że praca reprodukcyjna, szczególnie ta wykonywana nieodpłatnie przez kobiety, jest czymś więcej niż wyzwaniem dla teoretyczek. Jest przedmiotem rzeczywistych walk o jej dostrzeżenie i upolitycznienie, a także - o uwzględnienie roli kobiet $\mathrm{w}$ oderwaniu od rzekomej naturalności sfery domowych obowiązków.

Szczególnie w Polsce niezbędne wydaje się powiązanie szerszego ujęcia teoretycznego, umieszczającego pracę reprodukcyjną $\mathrm{w}$ sercu systemu kapitalistycznego $\mathrm{z}$ praktyką walk o sprawczość kobiet. Dzięki temu mobilizacja kobiet, przede wszystkim w ramach Czarnych Protestów i inicjatywy Ogólnopolski Strajk Kobiet, zyskuje nowe oblicze staje się walką przeciwko podporządkowaniu i wyzyskowi. W końcu walka o prawa reprodukcyjne to nie tylko walka przeciw państwu, Kościołowi czy mężczyznom chcącym decydować za kobiety o ich zdrowiu i życiu - jest to również walka przeciw kapitałowi, który w sferze reprodukcji ulokował swoje strategiczne interesy.

Dlatego też w niniejszym numerze postanowiliśmy zaprezentować dwa teksty przedstawicieli ruchu pracowniczego i działaczy OZZ Inicjatywa Pracownicza, którzy spieraja się o znaczenie pracy reprodukcyjnej dla kapitalistycznego sposobu produkcji oraz oporu wobec niego. W kontekście naszego numeru ich głosy są tym bardziej interesujące, że ze wspominanym problemem mierzą się w bezpośrednim odniesieniu do Marksowskiego Kapitału. O ile Florian Nowicki w tekście „Czy (i jak) kapitał zarabia na patriarchacie?” proponuje ortodoksyjne rozumienie pracy reprodukcyjnej, podążające tropem przemyśleń Marksa i Engelsa, jego polemista, Krzysztof Król problem pracy reprodukcyjnej postrzega przede wszystkim przez pryzmat zerwania stosunku kapitalistycznego. Tym samym mamy nadzieję, że zawarte w niniejszym numerze teksty poświęcone pracy reprodukcyjnej staną się elementem szerszej refleksji nad antykapitalistycznym wymiarem walk o prawa reprodukcyjne. 
CYTOWANIE: Praktyka Teoretyczna. 2017. „Wstęp do debaty o pracy reprodukcyjnej”. Praktylka Teoretyczna 3(25): 235-236.

DOI: $10.14746 /$ prt.2017.3.9

AUTHOR: Theoretical Practice

TITLE: Introduction to the Discussion 